\title{
PENINGKATAN KEMAMPUAN BERPIKIR MATEMATIS SISWA PADA MATERI BANGUN DATAR MELALUI MODEL PEMBELAJARAN PROYEK TERINTEGRASI STEM
}

\author{
Kanti Warih Ade Indriani \\ SMPN 4 Taliwang \\ Email:Warih80@gmail.com
}

\begin{abstract}
The problem of students' difficulties on shapes material (triangles) becomes the background of the researcher to carry out research using a project learning model that is integrated with the STEM approach. The purpose of research is to improve students' mathematical thinking abilities. The research subjects were students of class VIII SMPN 4 Taliwang. The instruments used were observation sheets and tests. In STEM-learning projects, students are trained to solve mathematical problems through projects that are integrated with other fields of science. This research is a classroom action research conducted in 2 cycles. Each cycle is carried out with 4 stages, namely planning, action, observation, and reflection. The results showed that the mathematical ability of students in cycle 1 achieved an average score of 72 with a classical completeness of 70\%, increasing in cycle 2 achieving an average score of 80 with a classical completeness of $83 \%$. Based on these data it can be concluded that through the application of the project learning model integrated STEM can improve students' mathematical thinking abilities on flat build material in class VIII SMPN 4 Taliwang.
\end{abstract}

Keywords: Project Based Learning, STEM, Mathematical Thinking Abilities, Shapes

Abstrak: Masalah kesulitan siswa pada materi bangun datar (segitiga) menjadi latar belakang peneliti untuk melaksanakan penelitian menggunakan model pembelajaran proyek yang diintegrasikan dengan pendekatan STEM. Tujuan penelitian adalah untuk meningkatkan kemampuan berpikir matematis siswa. Subyek penelitian adalah siswa kelas VIII SMPN 4 Taliwang. Instrument yang digunakan adalah lembar observasi dan tes. Dalam pembelajaran proyek-STEM, siswa dilatih memecahkan masalah matematika melalui proyek yang terintegrasi dengan bidang ilmu yang lain. Penelitian ini merupakan penelitian tindakan kelas yang dilaksanakan dalam 2 siklus. Setiap siklus dilaksanakan dengan 4 tahapan, yaitu perencanaan, tindakan, observasi, dan refleksi. Hasil penelitian menunjukkan bahwa kemampuan matematis siswa pada Siklus I mencapai skor rata rata 72 dengan ketuntasan klasikal 70\%, meningkat pada Siklus II mencapai skor rata rata 80 dengan ketuntasan klasikal 83\%. Berdasarkan data-data tersebut maka dapat disimpulkan bahwa melalui penerapan model pembelajaran proyek terintegrasi STEM dapat meningkatkan kemampuan berpikir matematis siswa pada materi bangun datar di kelas VIII SMPN 4 Taliwang.

Kata kunci: Project Based Learning, STEM, Kemampuan Berpikir Matematis , Bangun Datar

\section{PENDAHULUAN}

Sejalan dengan pembelajaran abad 21, di Indonesia menerapkan sistem pendidikan disebut dengan Kurikulum 2013. Menekankan pada kemampuan berpikir. Beberapa model pembelajaran yang digunakan di kurikulum 2013 adalah Problem Based Learning/PBL (pembelajaran berbasis masalah), Project based learning/PjBL (pembelajaran berbasis proyek), Discovery (penemuan) dan Inquiry (penemuan terbimbing). Dalam penelitian ini, pembelajaran matematika yang diterapkan menggunakan Project Based Learning atau pembelajaran proyek. PjBL adalah pembelajaran yang menggunakan proyek sebagai media. Siswa melakukan eksplorasi, penilaian, interpretasi, sintesis dan informasi. Dengan menggunakan masalah 
sebagai langkah awal dalam mengumpulkan dan mengintegrasikan pengetahuan baru berdasarkan pengalamannya dalam beraktifitas secara nyata. (Muslim, 2017)

Kelebihan PjBL ini adalah dapat meningkatkan motivasi belajar siswa dengan membuat siswa lebih aktif dan berhasil memecahkan masalah-masalah yang kompleks, meningkatkan kemampuan memecahkan masalah, meningkatkan kolaborasi, mendorong siswa untuk mengembangkan dan mempraktikkan keterampilan komunikasi, dan dapat meningkatkan keterampilan siswa dalam mengelola berbagai sumber (Raitu, 2018) Hal ini selaras dengan pendapat (Nurfitriyanti, 2016) bahwa PjBL project based learning juga memfasilitasi peserta didik untuk berinvestigasi, memecahkan masalah, bersifat students centered, dan menghasilkan produk nyata berupa hasil proyek. Oleh karena itu, berdasarkan tujuan penelitian ini adalah untuk mengetahui kemampuan berpikir matematis siswa, maka peneliti memilih PjBL dengan strategi pendekatannya menggunakan STEM (Science, Tecnology, Engineering, Mathematics).

STEM- Project Based learning, yaitu pembelajaran berbasis proyek dengan mengintegrasikan bidang-bidang STEM yaitu sains, teknologi, teknik, dan matematika. Pembelajaran menggunakan pendekatan STEM ini sangat potensial untuk menciptakan pembelajaran yang bermakna karena siswa dilatih memecahkan masalah matematika melalui proyek yang diterintegrasikan dengan satu atau bidang ilmu yang lain. Selain itu STEM juga memberikan pengalaman kepada siswa bahwa matematika bermanfaat nyata bagi kehidupan sehari-hari. Ismayani, (2016) menyatakan bahwa penerapan STEM yang diintegrasikan kedalam model pembelajaran Project Based Learning dapat memberikan pembelajaran yang bermakna, dan dapat memberikan pengalaman kepada siswa bahwa matematika bermanfaat nyata bagi kehidupan. Demikian pun (Supriyatun, 2019) juga mengeluarkan pendapat bahwa pembelajaran STEM dapat meningkatkan kemampuan berpikir kritis sehingga dapat diterapkan pada pembelajaran di kelas. Integrasi STEM dalam model pembelajaran dapat meningkatkan kemampuan pemecahan masalah dan dapat membantu membangun hubungannya dalam kehidupan nyata.

Salah satu contoh penerapan matematika dalam dunia nyata yang banyak kita jumpai disekitar kita adalah geometri. Setiap hari kita dihadapkan pada bentuk bangun-bangun. Diantaranya adalah segitiga dan segi empat. Mengingat pentingnya mempelajari geometri bagi kehidupan, maka pelajaran geometri ini diberikan sejak pendidikan dasar. Sejalan dengan pernyataan (Karim, 2015) menyatakan Siswa belajar suatu materi matematika dimulai dengan pemahaman terhadap materi tersebut, sehingga apa yang dipelajari oleh siswa dapat diaplikasikan untuk menyelesaikan masalah dalam kehidupan sehari-hari.

Tetapi fakta yang dihadapi guru di sekolah siswa masih mengalami kesulitan pada materi geometri. Khususnya untuk bangun datar segitiga, mereka kesulitan dalam menentukan alas dan 
tinggi dari sebuah segitiga. Jika segitiga yang ditampilkan adalah segitiga dengan posisi yang tidak ada sisi horisontal/lurus. Karena konsep siswa tentang alas dan tinggi secara matematis masih rancu dengan konsep alas dan tinggi dalam arti secara kontekstual kehidupan sehari-hari. Kesulitan yang dialami siswa juga terlihat dalam penyelesaian soal cerita yang melibatkan bangun-bangun geometri dimensi dua. Salah satu penyebab sulitnya siswa mempelajari matematika adalah karena objek yang dipelajari bersifat abstrak. Untuk memahami konsep abstrak siswa memerlukan benda-benda konkrit sebagai perantara atau visualisasinya. Hal ini selaras dengan penelitian yang dilakukan oleh (Yuwono, 2016).

Ditinjau dari masalah di atas, maka peneliti melakukan penelitian yang difokuskan pada bangun datar segitiga yaitu pada kompetensi dasar memahami garis-garis istimewa pada segitiga. Dengan bantuan media konkrit yaitu model bentuk-bentuk segitiga. Dengan tujuan agar siswa dapat memahami konsep alas, tinggi, sisi miring/apotema pada segitiga dan lebih jauh lagi siswa dapat memahami tentang garis tinggi, garis bagi, garis berat dan garis sumbu pada segitiga dengan tugas akhir pada penelitian ini adalah siswa dapat menerapkan konsepkonsep tersebut dengan membuat suatu produk model meja berkaki satu berdasarkan konsep titik tengah gabungan 2 segitiga.

Dengan konsep STEM yang diaplikasikan pada pembelajaran ini, diharapkan siswa dapat mengaitkan konsep segitiga tersebut (matematika) dengan bidang ilmu yang lain yaitu pada konsep gaya berat dan gravitasi (sains), merancang pembuatan model meja berkaki satu dengan permukaan berasal dari satu atau gabungan bentuk segitiga (teknik), sedangkan pemanfaatan teknologi di pembelajaran ini siswa dibiasakan untuk membaca atau mencari sumber belajar dari berbagai literatur, salah satunya dari internet. Dan siswa juga dilatih dalam memanfaatkan media elektronik dalam proses pelaporan dan presentasinya.

Lestari (2018) menyatakan bahwa pembelajaran menggunakan pendekatan STEM berdampak baik, diantaranya pada kemampuan berpikir matematis. STEM mampu meningkatkan pemahaman konsep, keterampilan bernalar siswa, dan kemampuan siswa dalam berpikir kritis serta kreatif. Salah satu keterampilan berpikir adalah berpikir matematis tingkat tinggi. Kemampuan berpikir matematis tingkat tinggi merupakan suatu kemampuan berpikir yang tidak hanya membutuhkan kemampuan menghafal atau mengingat saja, namun membutuhkan kemampuan lain yang lebih tinggi, seperti kemampuan berpikir kreatif dan kritis. Menurut Rofiah (2016) bahwa kemampuan berpikir merupakan proses berpikir yang tidak sekedar menghafal dan menyampaikan kembali informasi yang diketahui. Tetapi merupakan kemampuan menghubungkan, memanipulasi, dan mentransformasi pengetahuan serta pengalaman yang sudah dimiliki untuk berpikir secara kritis dan kreatif dalam upaya menentukan keputusan dan memecahkan masalah pada situasi baru. Diana (2014) dan Nursit 
(2016) juga menjelaskan bahwa kemampuan berpikir tingkat tinggi ini diperlukan dalam pemecahan masalah geometri.

Primasatya (2016) menyatakan bahwa proses yang dilalui seseorang dalam berpikir matematis, yaitu: 1) Specializing (mengkususkan); 2) Generalizing (mengeneralisasi); 3) Conjecturing (menduga); 4) Convincing (meyakinkan). Pendapat tersebut yang kemudian diadopsi oleh peneliti sebagai indikator penilaian kemampuan berpikir matematis siswa dalam penelitian ini. Secara lebih rinci indikator kemampuan berpikir matematis menurut Primasatya tersebut, yang diadopsi dari pendapat Stacey (2010) sebagai berikut

Tabel 1. Indikator Kemampuan Berpikir Matematis

\begin{tabular}{|l|l|}
\hline \multicolumn{1}{|c|}{ Proses Berpikir Matematis } & \multicolumn{1}{|c|}{ Indikator } \\
\hline Specializing (mengkhususkan) & Mengidentifikasi masalah \\
\hline Generalizing (menggeneralisasi) & Merefleksi ide/gagasan yang dibuat \\
Memperluas cakupan hasil yang dibuat
\end{tabular}

Berdasar uraian di atas, pada penelitian ini, peneliti ingin menerapan model pembelajaran Proyek yang terintegrasi pendekatan STEM sebagai upaya meningkatkan kemampuan berpikir matematis siswa pada materi bangun datar di kelas VIII SMPN 4 Taliwang.

\section{METODE}

Penelitian ini dilaksanakan di SMPN 4 Taliwang yang beralamat di jalan Kerato Permai no 7 desa Lalar Liang kecamatan Taliwang Kabupaten Sumbawa Barat. Penelitian ini merupakan Penelitian Tindakan Kelas (PTK). Penelitian ini dilaksanakan dari bulan Juli sampai dengan Oktober 2019. Subyek penelitian ini adalah siswa kelas VIII dengan jumlah siswa 23 orang. Siswa putri berjumlah 12 orang dan siswa putra 11 orang. Instrumen yang digunakan dalam mengumpulkan data adalah Lembar Observasi dan Lembar tes /evaluasi. Data penelitian diperoleh meliputi data hasil observasi keterlaksanaan pembelajaran dan data kemampuan berfikir matematis siswa.

Penelitian ini dilaksanakan dalam 2 siklus. Adapun prosedur penelitian yang diterapkan dalam penelitian ini mengacu pada model Kemmis dan Mc Taggart yang disampaikan Masjudin (2017) bahwa Langkah-langkah tersebut berupa siklus yang terdiri dari empat tahap, yaitu: perencanaan (plan), pelaksanaan tindakan (action), pengamatan (observation), dan refleksi (reflection)

Tahapan penelitian yang dilakukan dijabarkan sebagai berikut:

1. Menyiapkan instrument penelitian (tahap perencanaan). 
Kegiatan pada tahap ini adalah menyiapkan instrumen penelitian berupa silabus, Rencana Pelaksanaan Pembelajaran (RPP), Lembar Kerja Siswa (LKS), lembar observasi, dan lembar Evaluasi.

2. Melaksanakan aktivitas pembelajaran (Tahap Pelaksanaan Tindakan)

Pada tahap pelaksanaan tindakan ini, kegiatan yang dilakukan adalah melaksanakan pembelajaran sesuai sintaks Project Based Learning (PjBL) terintegrasi STEM. Pada pertemuan pertama setiap siklus dilakukan pree test untuk mendapatkan data kemampuan awal siswa. Begitupun pada pertemuan terakhir setiap siklus dilakukan Post test untuk mendapatkan data kemampuan berfikir matematis siswa setelah pelaksanaan tindakan.

Adapun pelaksaan tindakan pada Siklus I dilakukan sebanyak 2 kali pertemuan (5 jam pelajaran) dan pada siklus II dilakukan sebanyak 3 kali pertemuan.

3. Melakukan Observasi kegiatan (tahap observasi)

Kegiatan observasi pada tahap ini adalah melakukan pengamatan terhadap keterlaksanaan pembelajaran. Kegiatan ini dilaksaan bersamaan dengan pelaksanaan tindakan. Data yang dikumpulkan pada kegiatan observasi meliputi data keterlaksanaan pembelajaran yang dilakukan oleh guru dan data aktivitas siswa.

4. Merefleksi kegiatan (tahap refleksi)

Merefleksi kegiatan pembelajaran adalah melakukan analisis kelemahan dan kekurangan pada pembelajaran yang telah dilakukan dan merencanakan perbaikan berdasarkan permasalahan yang diperoleh.

Teknik analisis data menggunakan statistika sederhana dengan teknik triangulasi data yaitu melalui tahap pengumpulan data, verifikasi data dengan cara tabulasi, dan penyimpulan data secara deskriptif. Analisis data dilakukan dalam 2 hal yaitu analisis keterlaksanaan pembelajaran dan analisis kemampuan berpikir matematis. Analisis data untuk mengukur keterlaksanaan pembelajaran menggunakan instrument observasi pembelajaran aktivitas guru dan siswa. Observasi menggunakan skala likert dan diolah menggunakan statistik sederhana yaitu hanya menentukan jumlah dan rata-rata (mean) setelah itu nilai akan dikonversi kedalam skala 100 untuk menentukan kategori mutu. Sedangkan Analisis hasil belajar pada kemampuan representasi matematis siswa diperoleh dari nilai pretes dan postes, nilai ini diolah dengan pemberian skor. Kemudian ditetapkan presentase jumlah siswa yang memperoleh nilai melebihi standard yang ditetapkan (KKM) yaitu 73 atau kategori cukup. 


\section{HASIL DAN PEMBAHASAN}

\section{Hasil}

\section{A. Hasil Observasi}

Dari kegiatan Observasi pembelajaran guru yang menerapkan pembelajaran model PjBLSTEM yang sudah dilaksanakan diperoleh data Keterlaksanaan Pembelajaran sebagai berikut:

Tabel 2. Hasil Analisis Observasi Aktivitas Guru

\begin{tabular}{|c|c|c|c|}
\hline NO & Aktivitas PjBL & Siklus I & Siklus II \\
\hline 1 & Pendahuluan & 68,8 & 87,5 \\
\hline 2 & Aktivitas pada penentuan proyek & 75 & 75 \\
\hline 3 & $\begin{array}{l}\text { Aktivitas pada perancangan langkah-langkah penyelesaian } \\
\text { proyek }\end{array}$ & 75 & 87,5 \\
\hline 4 & Aktivitas pada penyusunan jadwa pelaksanaan proyek & 50 & 75 \\
\hline 5 & $\begin{array}{l}\text { Aktivitas pada penyelesaian proyek dengan fasilitasi dan } \\
\text { monitoring guru }\end{array}$ & 75 & 87,5 \\
\hline 6 & $\begin{array}{l}\text { Aktivitas pada penyusunan laporan dan presentasi/publikasi } \\
\text { hasil proyek }\end{array}$ & 87,5 & 87,5 \\
\hline \multirow[t]{4}{*}{7} & Penutup & 75 & 93,75 \\
\hline & Jumlah & 506,3 & 593,8 \\
\hline & Skor pencapaian & 72,3 & 84,8 \\
\hline & Kategori & Baik & Sangat Baik \\
\hline
\end{tabular}

Berdasarkan data yang disajikan pada Tabel 2 di atas, diperoleh informasi bahwa pencapaian keterlaksanaan pembelajaran guru berkategori baik dan sangat baik. Bahkan dari Siklus I ke Siklus II terdapat peningkatan. Dengan demikian, penerapan pembelajaran model PjBL-STEM yang dilakukan oleh guru sudah terlaksana dengan baik dan lancar.

Adapun hasil analisis observasi aktivitas siswa pada pembelajaran menggunakan model pembelajaran PjBL-STEM yang sudah dilaksanakan diperoleh data sebagai berikut:

Tabel 3. Hasil Observasi Aktivitas Siswa

\begin{tabular}{|llccc|}
\hline NO & Aktivitas PjBL & Siklus I & Siklus II \\
\hline 1 & Pendahuluan & 50 & 83 \\
\hline 2 & Aktivitas pada penentuan proyek & 63 & 75 \\
\hline 3 & Aktivitas pada perancangan langkah-langkah penyelesaian proyek & 50 & 75 \\
\hline 4 & Aktivitas pada penyusunan jadwa pelaksanaan proyek & 25 & 88 \\
\hline 5 & $\begin{array}{l}\text { Aktivitas pada penyelesaian proyek dengan fasilitasi dan } \\
\text { monitoring guru }\end{array}$ & 50 & 75 \\
\hline 6 & $\begin{array}{l}\text { Aktivitas pada penyusunan laporan dan presentasi/publikasi hasil } \\
\text { proyek }\end{array}$ & 33 & 83 \\
\hline 7 & Penutup & 50 & 67 \\
\hline & Jumlah & 321 & 546 \\
\hline & rata-rata & & 77,98 \\
\hline
\end{tabular}

Berdasarkan data yang disajikan pada Tabel 3 di atas diperoleh informasi bahwa pencapaian aktivitas siswa dalam belajar berada pada kategori cukup dan baik. Terdapat 
peningkatan capaian siswa dari Siklus I ke Siklus II. Dengan demikian, keterlibatan siswa dalam belajar dengan pembelajaran model PjBL-STEM terus meningkat, siswa semakin mampu menyesuaikan diri dengan pembelajaran yang diterapkan.

B. Hasil Evaluasi

Hasil evaluasi dari pre tes dan postes yang dilaksanakan diperoleh data hasil analisis adalah sebagai berikut:

Tabel 4. Rekapitulasi Data Kemampuan Berfikir Matematis Siswa

\begin{tabular}{|c|c|c|c|}
\hline Tahap & Pre tes & Postes & Ketuntasan Klasikal \\
\hline Siklus I & 25 & 72 & $70 \%$ \\
\hline Siklus II & 35 & 80 & $83 \%$ \\
\hline
\end{tabular}

Berdasarkan data yang disajikan pada Tabel 4 di atas diperoleh informasi bahwa pencapaian kemampuan berfikir matematis dari Siklus I ke Siklus II mengalami peningkatan. Bahkan pada siklus II, ketuntasan klasikal yang diperoleh mencapai 83\% siswa tuntas. Dengan demikian, kemampuan berfikir matematis siswa setelah belajar dengan pembelajaran model PjBL-STEM telah sesuai dengan target yang diharapkan.

\section{PEMBAHASAN}

Tujuan dilaksanakan penelitian ini adalah untuk meningkatkan kemampuan berfikir matematis siswa melalui penerapan model pembelajaran proyek terintegrasi STEM pada materi bangun datar di kelas VIII SMPN 4 Taliwang. Berdasarkan data yang telah disajikan pada hasil penelitian, dapat diambil suatu informasi bahwa tujuan tersebut sudah tercapai dengan melihat adanya berbagai capaian peningkatan dari siklus I ke siklus II.

Hasil observasi keterlaksanaan pembelajaran yang diperoleh dari observasi pembelajaran yang dilakukan oleh observer terhadap kegiatan pembelajaran guru dan observasi aktivitas siswa menaglami peningkatan. Dilihat dari tabel hasil observasi kegiatan pengajaran guru pada siklus satu diperoleh skor penilaian 72,3 dengan kategori baik. Sedangkan pada siklus kedua diperoleh skor penilaian 84,8 . Skor ini termasuk kedalam kategori sangat baik. Dari data tersebut dapat dikatakan pembelajaran yang dilakukan oleh guru berhasil karena mengalami peningkatan dari Siklus I ke Siklus II.

Selanjutnya, hasil observasi aktivitas siswa menunjukkan skor 45,83 pada Siklus I dan 77,98 pada Siklus II. Dilihat dari kategorinya pada Siklus I termasuk kedalam kategori cukup dan mengalami peningkatan di siklus kedua menjadi kategori baik. Dilihat dari peningkatan pembelajaran yang dilakukan guru mencapai kategori sangat baik serta peningkatan aktivitas siswa pada siklus kedua ini mencapai kategori baik, hal ini berarti pencapaian hasil penelitian sesuai target yang ditetapkan. 
Peningkatan ini terjadi karena guru telah berusaha memperbaiki kualitas pengajarannya pada setiap pertemuan dan setiap siklusnya. Perbaikan ini dilakukan berdasarkan hasil observasi dan refleksi pada setiap pertemuan. Pada siklus I pertemuan pertama, ada beberapa catatan yang diperoleh dari observer yang perlu diperbaiki. Diantaranya:

a. Belum optimalnya pembelajaran yang disampaikan

b. Manajemen waktu perlu diperbaiki

c. Beberapa siswa masih kebingungan dalam menghubungkan konsep kedalam symbol dan prosedur operasi hitung.

d. Dalam hal bahasa, siswa masih malu karena belum terbiasa dalam mempresentasikan hasil diskusi kelompok

e. Pengorganisasian kelompok dan kerjasama belum Nampak

Pada pertemuan ke dua, guru melakukan perbaikan dan penyempurnaan sehingga pada pertemuan kedua ini pembelajaran semakin baik. Respon yang guru dapatkan dari observer pada pertemuan kedua menjadi positif. Diantara respons dari observer yaitu:

a. Antusisme siswa sangat tinggi.

b. Siswa sangat aktif dan kooperatif selama pembelajaran

c. Namun masih ada siswa yang bersikap acuh terhadap pembelajaran dikarenakan belum sepenuhnya menguasai materi

Selanjutnya pada siklus II, pelaksanaan pembelajaran semakin berjalan lancar. Refleksi atas pembelajaran guru sebelumnya sangat membantu guru memperbaiki kualitas pembelajarannya. Dampaknya adalah Respon/komentar dari observer juga semakin baik. Berikut ini komentar dari observer pada siklus II.

a. Kemampuan siswa mempresentasikan hasil diskusi semakin baik dan terarah.

b. Siswa lebih aktif dan kooperatif selama pembelajaran

c. Kekompakan kerja kelompok sudah terorganisir dengan baik

d. Siswa lebih aktif dan kooperatif selama mengerjakan proyek.

e. Kekompakan kerja kelompok sudah terorganisir dengan baik Tidak ada lagi siswa yang acuh selama proses pembelajaran

Catatan dan komentar dari observer yang diberikan kepada guru dalam mengimplementasikan model pembelajaran proyek terintegrasi STEM sangat membantu guru yang sekaligus menjadi peneliti untuk memperbaiki pembelajaran ini.

Pada implementasi Model pembelajaran proyek terintegrasi STEM kendala terberat yang guru temui adalah bagaimana melibatkan siswa terlibat aktif dalam pembelajaran, terutama saat mengerjakan proyek. Namun, kendala tersebut bias teratasi dengan pembelajaran kelompok yang terdiri dari berbagai kemampuan, baik yang berkemampuan rendah, sedang, dan tinggi. 
Dengan cara itu, siswa siswa dapat berdiskusi dalam menyelesaikan proyek. Hal ini sejalan dengan temuan Masjudin (2017) bahwa belajar secara berkelompok memberikan banyak keuntungan bagi siswa. Dalam belajar kelompok, siswa saling berdiskusi dan bertukar pikiran dalam menyelesaikan masalah yang diberikan. Para siswa saling memberikan bantuan dan masukan dalam meningkatkan pemahamannya tentang suatu konsep yang dipelajari.

Hasil observasi pembelajaran juga berbanding lurus dengan hasil evaluasi kemampuan berfikir matematis siswa. Ditinjau dari data hasil pre tes dan postes yang sudah dilaksanakan, pada siklus pertama diperoleh rata-rata skor perolehan siswa 25 dan pada pos tes Siklus I rata-rata skor pencapaian siswa adalah 72. Yang artinya terdapat peningkatan pada siklus ini. Sedangkan pada siklus kedua, nilai pre tes siswa adalah 35 dan pada pos tes siklus kedua ini mencapai 80. Dengan demikian, skor perolehan kemampuan berfikir matematis siswa telah meningkat.

Berdasarkan jumlah siswa yang tuntas pada pelaksanaan pre tes dan postes ditinjau dari KKM KD ini adalah 70 dan dari total jumlah siswa 23 orang, maka dapat dijabarkan sebagai berikut: pada siklus pertama, 16 orang siswa tuntas, dengan ketuntasan klasikal 70\%. Pada siklus kedua ada 19 orang siswa tuntas dengan ketuntasan klasikal 83\%. maka dapat disimpulkan bahwa target penelitian yang ditetapkan tercapai.

Implementasi model pembelajaran proyek terintegrasi STEM memberikan kontribusi baik sebagai upaya meningkatkan kemampuan berpikir matematis siswa pada materi segitiga. Melalui specializing (mengkhususkan), siswa dapat mengidentifikasi masalah dan menjelaskan cara menentukan garis tengah segitiga menggunaan konsep garis-garis istimewa. Siswa juga dapat melakukan generalizing (menggeneralisasi), siswa dapat merefleksikan ide/gagasan menggunakan konsep tersebut pada pengembangan materi gabungan bangun segitiga. Selanjutnya melalui conjecturing (menduga), siswa dapat mengaitkan konsep secara kontekstual kedalam permasalahan matematika. Dan terakhir melalui convincing (meyakinkan) nampak pada saat siswa presentasi hasil, mereka dapat menjelaskan konsep garis istimewa dalam menentukan titik tengah gabungan 2 segitiga dengan baik, artinya siswa memahami konsep garis-garis istimewa pada segitiga untuk menentukan titik tengah gabungan dua segitiga.

Dengan kemampuan berfikir matematis yang baik, siswa dapat menyelesaikan masalah secara baik. Dari implementasi pembelajaran menggunakan PjBL-STEM dalam penelitian ini siswa menghasilkan suatu produk berupa meja berkaki satu menggunakan konsep titik tengah segitiga dan materi gaya berat dan gravitasi, seperti yang nampak dalam tabel dibawah ini: 


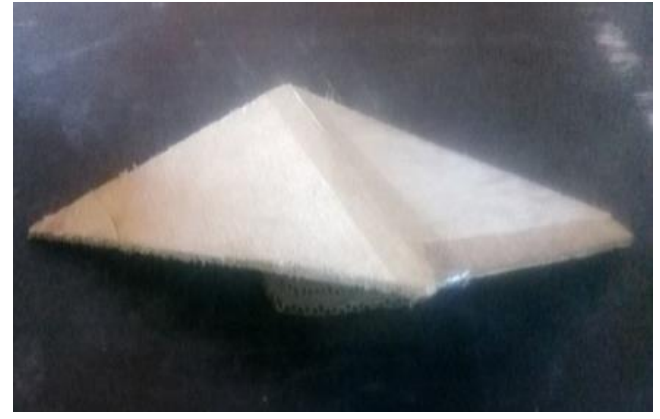

Gb 1. Hasil kerja kelompok 1

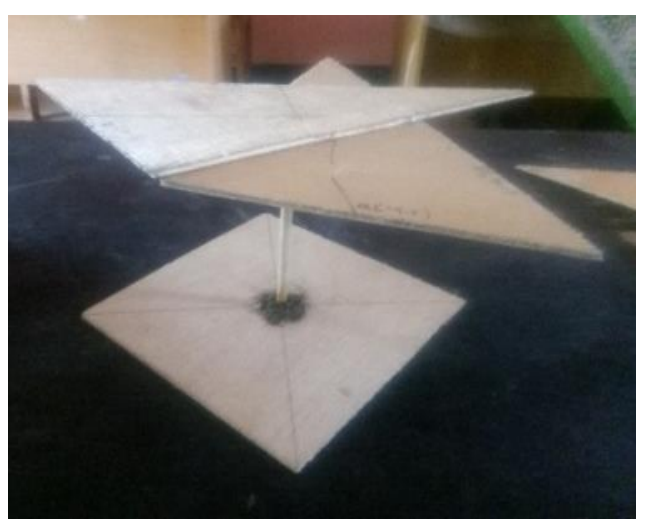

Gb 3. Hasil kerja kelompok 3

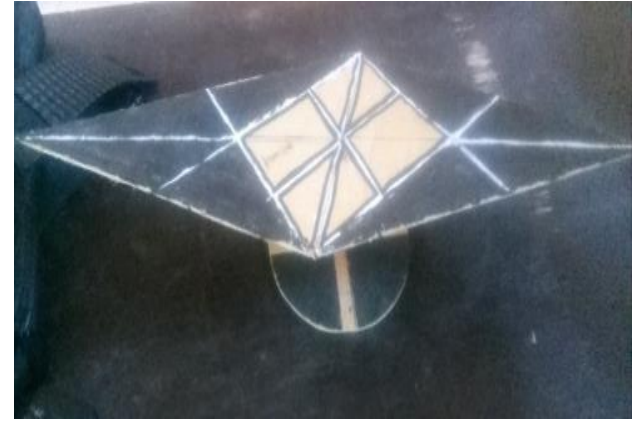

Gb 2. Hasil kerja kelompok 2

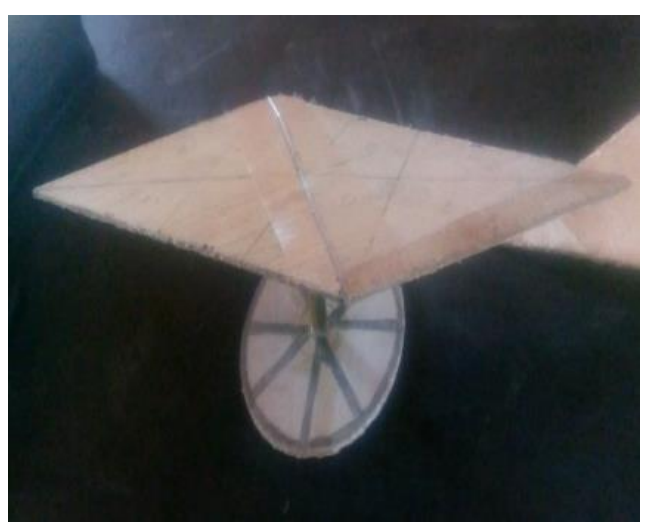

Gb 4. Hasil kerja kelompok 4

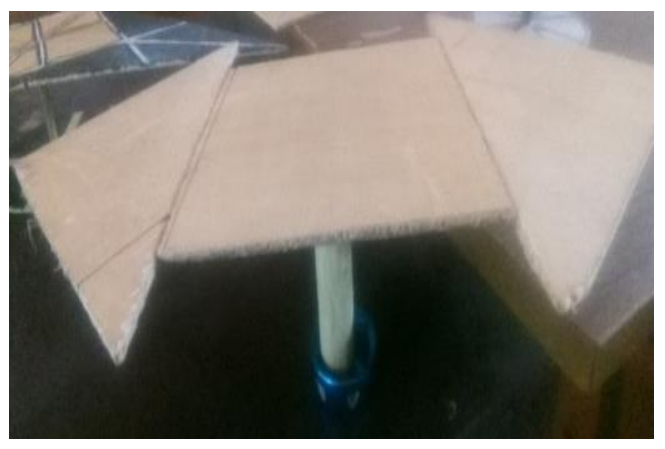

Gb 5. Hasil kerja kelompok 5

Produk ini dikerjakan oleh siswa yang bekerja dalam kelompok. Dengan menerapkan konsep STEM, outcome dari produk model meja ini adalah siswa dapat menetapkan titik tengah pada gabungan bangun segitiga. Yang merupakan integrasi matematika dalam materi garis istimewa pada segitiga dan sains dalam materi menentukan titik pusat massa benda, serta Teknik dalam mendesain model meja.

Hasil produk-produk tersebut menunjukkan bahwa pada kelompok 1 sampai kelompok 4 memahami konsep menentukan titik tengah pada gabungan dua segitiga, tetapi pada Kelompok 5 menambahkan bangun persegi ditengah gabungan dua segitiga. Hal ini berarti bahwa kelompok lima masih belum memahami instruksi dan tujuan pembelajaran yaitu menentukan titik tengah gabungan 
dua segitiga menggunakan konsep garis istimewa segitiga. Yang artinya kemampuan matematis kelompok lima masih kurang dibandingkan dengan kelompok yang lain.

Berdasarkan uraian di atas dapat ditarik suatu benang merah bahwa pembelajaran menggunakan model pembelajaran Proyek terintegrasi STEM ini efektif untuk diterapkan pada pembelajaran matematika khususnya di materi geometri. Hasil penelitian ini sesuai dengan penelitian Sumarni, W., Wijayati, N., \& Supanti, S. (2019) menyatakan bahwa pembelajaran proyek-STEM dapat meningkatkan kemampuan kognitif siswa dalam pemahaman konsep siswa dan kemampuan berpikir kreatif siswa. Sedangkan melalui pemanfaatan media konkret pada materi segitiga ini siswa dapat memahami konsep keliling, luas, dan garis-garis istimewa segitiga dengan baik Sejalan dengan penelitian (Yeni, 2011) bahwa pemanfaatan benda-benda manipulatif dapat meningkatkan pemahaman konsep geometri dan kemampuan tilikan ruang.

\section{KESIMPULAN DAN SARAN}

\section{Kesimpulan}

Berdasarkan hasil analisis data dan pembahasan dapat disimpulkan bahwa melalui penerapan model pembelajaran proyek terintegrasi STEM dapat meningkatkan kemampuan berfikir matematis siswa pada materi bangun datar di kelas VIII SMPN 4 Taliwang.

\section{Saran}

Berdasarkan temuan-temuan peneliti dalam mengimplementasi model pembelajaran proyek terintegrasi STEM maka dapat diberikan rekomendasi sebagai berikut:

1. Bagi guru yang ingin menerapkan model pembelajaran proyek terintegrasi STEM, sebaiknya mengahdirkan aktivitas dan media pembelajaran visual agar dapat dipahami dengan baik oleh siswa. Terutama dalam mengajarkan materi geometri

2. Bagi peneliti lainnya, disarankan untuk melakukan penelitian dengan menerapkan Pembelajaran proyek-STEM pada materi, maupun variable yang lainnya.

\section{Ucapan Terimakasih}

Ucapan terimakasih ini ditujukan kepada semua pihak yang telah memberikan dukungan dan bantuan kepada penulis sehingga penyusunan PTK ini dapat terlaksana dengan baik. Dengan segala kerendahan hati, penulis menyampaikan terimakasih yang setinggi-tingginya kepada: bapak Janaruddin, S,Pd selaku kepala sekolah SMPN 4 Taliwang, bapak Misbahussurrur sebagai kolaborator (teman sejawat), dan siswa-siswi kelas VIII atas kerjasama dan partisipasinya. 


\section{DAFTAR PUSTAKA}

Diana, N., \& Mariamah, M. (2014). Profil Berpikir Kritis Siswa Smp Dalam Pemecahan Masalah Geometri Ditinjau Dari Gaya Belajar. Media Pendidikan Matematika, 2(2), 151161.

Ismayani, A. (2016). Pengaruh Penerapan STEM Project-Based Learning Terhadap Kreativitas Matematis Siswa SMK. Indonesian Digital Journal Of Mathematics And Education, 3(4), 264-272.

Karim, A. (2015). Pengaruh gaya belajar dan sikap siswa pada pelajaran matematika terhadap kemampuan berpikir kritis matematika. Formatif: Jurnal Ilmiah Pendidikan MIPA, 4(3).

Lestari, D. A. B., Astuti, B., \& Darsono, T. (2018). Implementasi LKS Dengan Pendekatan STEM (Science, Technology, Engineering, And Mathematics) Untuk Meningkatkan Kemampuan Berpikir Kritis Siswa. Jurnal Pendidikan Fisika Dan Teknologi, 4(2), 202207.

Masjudin, M. (2017). Pembelajaran Kooperatif Investigatif Untuk Meningkatkan Pemahaman Siswa Materi Barisan Dan Deret. Jurnal Edukasi Matematika dan Sains, 4(2), 76-84.

Muslim, S. R. (2017). Pengaruh Penggunaan Model Project Based Learning Terhadap Kemampuan Pemecahan Masalah Matematik Peserta Didik SMA. SJME (Supremum Journal of Mathematics Education), 1(2), 88-95.

Nurfitriyanti, M. (2016). Model Pembelajaran Project Based Learning terhadap Kemampuan Pemecahan Masalah Matematika. Formatif: Jurnal Ilmiah Pendidikan MIPA, 6(2).

Nursit, I. (2016). Pengembangan Multimedia Interaktif Berbasis Power Point (Macro-Enabled) Pada Mata Kuliah Geometri Euclid Dalam Pembelajaran Matematika. Media Pendidikan Matematika, 4(1), 41-49.

Primasatya, N. (2016). Analisis Kemampuan Berpikir Matematis Calon Guru Sekolah Dasar Dalam Menyelesaikan Masalah Matematika. JPM: Jurnal Pendidikan Matematika, 2(1), $50-57$.

Raitu, H., \& Kurniawan, A. (2018). Pengaruh Model Project Based Learning Dengan Tugas Creative Mind Map Terhadap Kemampuan Koneksi Matematika Dan Hasil Belajar Siswa. Media Pendidikan Matematika, 4(2), 57-63.

Sumarni, W., Wijayati, N., \& Supanti, S. (2019). Analisis Kemampuan Kognitif Dan Berpikir Kreatif Siswa Melalui Pembelajaran Berbasis Proyek Berpendekatan Stem. J-Pek (Jurnal Pembelajaran Kimia), 4(1), 18-30.

Supriyatun, S. E. (2019). Implementasi pembelajaran sains, teknologi, engineering, dan matematika STEM pada materi fungsi kuadrat. JUMLAHKU: Jurnal Matematika Ilmiah STKIP Muhammadiyah Kuningan, 5(1), 80-87.

Yeni, E. M. (2011). Pemanfaatan Benda-Benda Manipulatif Untuk Meningkatkan Pemahaman Konsep Geometri Dan Kemampuan Tilikan Ruang Siswa Kelas V Sekolah Dasar. Jurnal Edisi Khusus, 1, 63-75

Yuwono, M. R. (2016). Analisis Kesulitan Belajar Siswa Kelas VII SMP dalam Menyelesaikan Soal Materi Segitiga dan Alternatif Pemecahannya. Magistra, 28(95). 